\title{
Implantation of VVI epicardial pacemaker through mini-sternotomy in a patient with superior vena cava occlusion after radiotherapy
}

\author{
Karol Bartczak ${ }^{1}$, Arkadiusz Ammer ${ }^{1}$, Maciej Bartczak ${ }^{1}$, Krzysztof Kaczmarek $^{2}$, Ryszard Jaszewski ${ }^{1}$ \\ ${ }^{1}$ Department of Cardiac Surgery, Medical University of Łódź, Poland \\ ${ }^{2}$ Department of Electrocardiology, Medical University of Łódź, Poland
}

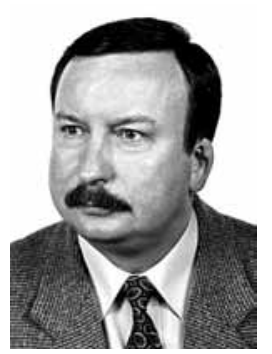

Kardiochirurgia i Torakochirurgia Polska 2014; 11 (1): 69-70

\begin{abstract}
The paper presents a case report of a patient with a superior vena cava occlusion and post-operational (after the implantation of the aortic valve) atrioventricular block, which required constant stimulation. An epicardial VVI pacemaker was implanted through mini-sternotomy in the lower part of the previous operation field with very satisfactory stimulation parameters. Implantation of a screw-in epicardial lead is in some cases the method of choice, which provides efficient and constant heart stimulation.

Key words: screw-in epicardial lead, pacemaker implantation, mini-sternotomy, superior vena cava occlusion.
\end{abstract}

\section{Case report}

The paper presents the case of a 57-year-old female patient operated on in 2011 due to critically calcified aortic stenosis. The patient underwent a splenectomy, lymphadenectomy and radiotherapy (Co-60 radiation) due to Lennert lymphoma in 1978. The patient suffered from chronic atrial fibrillation (AF) and was operated on using extracorporeal circulation in 2011 - the aortic valve was replaced with a mechanical ATS cardiac valve prosthesis. In the postoperational period, a third-degree atrioventricular block occurred, which required constant stimulation with an external pacemaker. The implemented treatment with steroids did not relieve the atrioventricular block. A decision to implant a permanent pacemaker was taken on day 12 after the surgery.

A total blood flow blockage in the brachiocephalic vein (Fig. 1A) was found during the puncture of the left subclavian vein. During the course of puncturing the right subclavian vein, critical stenosis and tortuosity of the superior vena cava were discovered, which prohibited placement of the lead (Fig. 1B). The typical implantation was discontin-

\section{Streszczenie}

W pracy omówiono przypadek pacjenta z okluzją żyły głównej górnej i pooperacyjnym (po implantacji zastawki aortalnej) blokiem przedsionkowo-komorowym, wymagającym stałej stymulacji. Nasierdziowy stymulator VVI został wszczepiony techniką ministernotomii $w$ dolną część uprzedniego pola operacyjnego z bardzo zadowalającymi parametrami stymulacji. Implantacja wkręcanej elektrody nasierdziowej jest w niektórych przypadkach metodą preferowaną, umożliwiającą stałą i efektywną stymulację serca.

Słowa kluczowe: wkręcana elektroda nasierdziowa, wszczepienie stymulatora serca, ministernotomia, okluzja żyły głównej górnej.

ued. After a careful analysis of various options, a decision was taken on the $14^{\text {th }}$ day after the surgery to implant an epicardial screw-in lead into the right apex of the heart through mini-sternotomy in the lower part of the previous operation field. After the sight-inspected preparation of the area, a Medtronic 5071-35 cm electrode was implanted (Fig. 1C). When the stimulation parameters had been examined (which did not differ from the results obtained in the case of a traditional endocavitary screw-in lead), the lead wire was connected to the Biotronik Talos pacemaker placed in the left hypochondriac region. On the $3^{\text {rd }}$ day after the surgery the patient was discharged from hospital. The results of the stimulation parameter control examination performed 12 months after the operation were satisfactory.

\section{Discussion}

The presented case study is very complex. The previously applied therapy with the use of radiation (Co-60th) had probably contributed to the occlusion of both the left subclavian vein and the superior vena cava, which rendered the placement of a pacemaker in the typical manner im

Address for correspondence: Karol Bartczak, Department of Cardiac Surgery, Medical University of Łódź, 1/3 Sterlinga Str., 91-425 Łódź, Poland, phone: +48 6013690 26, e-mail: bartczakkarol@op.pl 


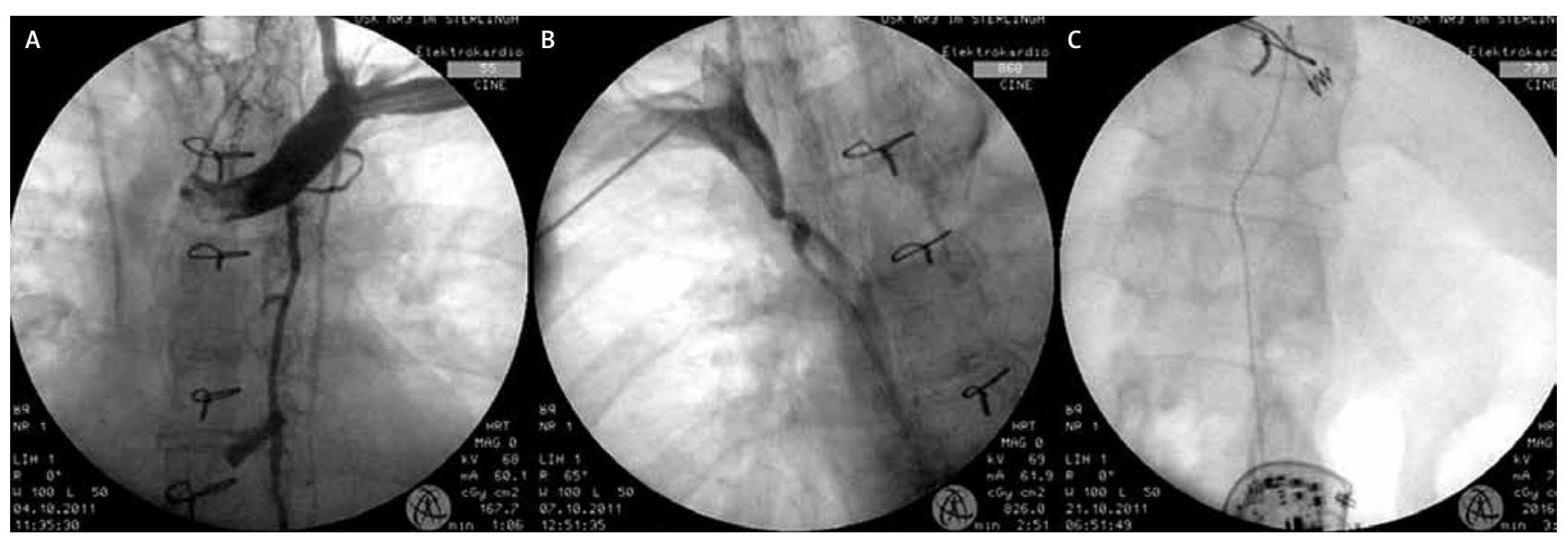

Fig. 1. Description in the text

possible. The presently applied method has not frequently been used in adults, yet in this case, the stimulation of the right apex of the heart was completely satisfactory, since the patient suffered from chronic atrial fibrillation. The surgery requires only a relatively small incision $(5-6 \mathrm{~cm})$ within the existing scar tissue. The aforementioned case, due to anatomical reasons, required the application of such a procedure, which seems futile particularly in patients who have experienced cardiac device-related infective endocarditis.

Other modes of implantation that have been described by several authors, e.g. through the azygos vein [1, 2], the inferior vena cava [3], a femoral vein and the iliac vein [4, 5], entail a potentially greater possibility of rupture or injury to the whole system. They also impose some restrictions on the physical activities of patients with a pacemaker implanted using these methods. Thrombosis in these vessels may pose a significant problem in the patients' further therapy. Since we are usually dealing with elderly people who require e.g. hemodialyses, this often entails an infection of the implanted system.

The current rapid progress in low-invasive techniques makes it possible to implant complex stimulation systems via epicardial leads through left-side mini-sternotomy. Opponents of epicardial stimulation claim that it is less physiological, increases the resistance of the implanted lead [6] and causes greater exhaustion of the pacemaker, even when steroid electrodes are used [7]. The method presented in this study does not confirm these reports. Results of a 5-year follow-up observation of 16 patients, whose electrical conduction system of the heart had to be prosthetized, are promising and will soon be published.

Complex systems can also be implanted using transaxillary minithoracotomy. Sako et al. reported that it was fully justified in some patients [8]. Placing a pacemaker in the pectoral region [8] or under the rectus abdominis muscle - as suggested by the authors of the present report - depends on the operator's experience.

\section{Conclusions}

The implantation of the screw-in epicardial lead is in some cases the method of choice, which provides efficient and constant heart stimulation. Evidently, each individual case requires a detailed analysis and the applied method should, above all, help the patient and by no means do any harm to them.

\section{References}

1. Kamdar RH, Schilling RJ. Percutaneous permanent pacemaker implantation via the azygous vein in a patient with superior vena cava occlusion. Pacing Clin Electrophysiol 2008; 31: 386-388.

2. Goktekin O, Besoglu Y, Dogan SM, Birdane A, Unalir A, Gorenek B, Kudaiberdieva G, Cavusoglu Y, Ata N, Aslan R, Timuralp B. Permanent pacemaker lead implantation via azygous vein in a patient with silent superior vena cava syndrome. Int J Cardiol 2007; 117: e4-6.

3. Brueck M, Bandorski D, Kramer W, Rauber K. Inferior vena cava approach to permanent pacemaker implantation. Pacing Clin Electrophysiol 2007; 30: 813-816.

4. Mathur G, Stables RH, Heaven D, Ingram A, Sutton R. Permanent pacemaker implantation via the femoral vein: an alternative in cases with contraindications to the pectoral approach. Europace 2001; 3: 56-59.

5. Erdogan O, Augostini R, Saliba W, Juratli N, Wilkoff BL. Transiliac permanent pacemaker implantation after extraction of infected pectoral pacemaker systems. Am J Cardiol 1999; 84: 474-475.

6. De Cock C, Stooker W, Visser CA. Unusual approach of a pacemaker electrode in a patient with a silent superior vena cava syndrome. Pacing Clin Electrophysiol 1998; 21: 1167-1169.

7. Udink ten Cate F, Breur J, Boramanand N, Crosson J, Friedman A, Brenner J, Meijboom E, Sreeram N. Endocardial and epicardial steroid lead pacing in the neonatal and paediatric age group. Heart 2002; 88: 392-396.

8. Sako H, Hadama T, Shigemitsu O, Miyamoto S, Anai H, Wada T, Iwata E, Hamamoto H. An implantation of DDD epicardial pacemaker through ministernotomy in a patient with a superior vena cava occlusion. Pacing Clin Electrophysiol 2003; 26: 778-780. 